\title{
Alterations of Amino Acids and Monoamine Metabolism in Male Fmr1 Knockout Mice: A Putative Animal Model of the Human Fragile X Mental Retardation Syndrome
}

\author{
Michael Gruss and Katharina Braun \\ Otto von Guericke University Magdeburg, Institute for Biology and Leibniz Institute for \\ Neurobiology, Project Group Juvenile Learning; Brenneckestr. 6, 39118 Magdeburg, Germany
}

\begin{abstract}
The Fragile $X$ syndrome, a common form of mental retardation in humans, is caused by silencing the fragile $X$ mental retardation (FMR1) gene leading to the absence of the encoded fragile $X$ mental retardation protein 1 (FMRP). We describe morphological and behavioral abnormalities for both affected humans and Fmr1 knockout mice, a putative animal model for the human Fragile $X$ syndrome. The aim of the present study was to identify possible neurochemical abnormalities in Fmr1 knockout mice, with particular focus on neurotransmission. Significant region-specific differences of basal neurotransmitter and metabolite levels were found between wildtype and Fmr1 knockout animals, predominantly in juveniles (post-natal days 28 to 31). Adults (postnatal days 209 to 221) showed only few abnormalities as compared with the wildtype. In juvenile knockout mice, aspartate and taurine were especially increased in cortical regions, striatum, hippocampus, cerebellum, and brainstem. In addition, juveniles showed an altered balance between excitatory and inhibitory amino acids in the caudal cortex,
\end{abstract}

Reprint requests to: Dr. Michael Gruss, Otto von Guericke University Magdeburg, Institute for Biology, Brenneckestr. 6, 39118 Magdeburg, Germany

e-mail: michael.gruss@nat.uni-magdeburg.de hippocampus, and brainstem. We detected very few differences in monoamine turnover in both age stages. The results presented here provide the first evidence that lack of FMRP expression in FMRP knockout mice is accompanied by age-dependent, region-specific alterations in neurotransmission.

\section{KEYWORDS}

aspartate, taurine, monoamines, development, HPLC

\section{INTRODUCTION}

The Fragile $\mathrm{X}$ syndrome, associated with a chromosomal abnormality, is one of the most common forms of inherited mental retardation in humans (Oostra, 1996; Jin \& Warren, 2000). The Fragile $\mathrm{X}$ syndrome is based on a large expansion of a CGG repeat sequence (more than 200 to 230 copies in the full mutation) in the $5^{\prime}$ - untranslated region of the fragile $\mathrm{X}$ mental retardation (FMR1) gene (Fu et al., 1991; Oberle et al., 1991; Verkerk et al., 1991). Caused by this repeat expansion, a hyper-methylation takes place in a $\mathrm{CpG}$ island, including the promotor region, resulting in an inactivation of the fragile $\mathrm{X}$ mental retardation protein 1 gene (FMR 1 gene), loss of expression of FMR1 mRNA transcripts (Pieretti et al., 1991), 
and absence of the encoded fragile $\mathrm{X}$ mental retardation protein (FMRP) (Devys et al., 1993).

The syndrome, which occurs more frequently in males than in females (Oostra, 1996; Comery et al., 1997), is characterized by a mild to severe mental retardation (IQ between 20 and 60) with notable deficits in language, visuo-spatial memory, attention, and executive functions in humans (Freund \& Reiss, 1991). In addition, emotional and psychosocial deficits have been described, including hyperactivity and autism (Baumgardner et al., 1995; Hagerman, 1996; Turk \& Graham, 1997; Bailey et al., 1998). The brain pathology of these patients includes abnormalities in the cerebellum (Reiss et al., 1991a; 1991b), decreased volume of the superior temporal gyrus (Reiss et al., 1994), and an enlarged volume of the caudate nucleus (Reiss et al., 1995). On the cellular level, immature spine morphology and reduced synaptic size have been observed in autopsy material from patients suffering from Fragile X syndrome (Rudelli et al., 1985; Hinton et al., 1991; Irwin et al., 2000; 2001).

That finding that the FMRP gene is highly conserved among species, including mice (Verkerk et al., 1991; Ashley et al., 1993a; 1993b), and that the expression pattern at the mRNA and protein level is almost identical in different tissues of human and mice (Abitbol et al., 1993; Bachner et al., 1993; Devys et al., 1993; Hinds et al., 1993; Khandjian et al., 1995), together with the identification of a murine homologue of the FMR1, led to the generation of the Fmrl knockout mouse, which can serve as an animal model for the experimental analysis of the Fragile $\mathrm{X}$ syndrome (Dutch-Belgian Fragile X Consortium, 1994). Although the nature of the mutation in the mouse model (gene interruption by insertion of a neomycin cassette into exon 5 of $\mathrm{Fmrl}$ ) is different from that observed in most Fragile $\mathrm{X}$ syndrome patients (CGG repeat amplification), both changes within the genome lead to the silencing of the synthesis of functional mRNA or protein (Oostra \& Hoogeveen,
1997). Previous studies characterizing the animal model drew attention to the behavioral and morphological differences between normal and muted mice that match, at least in part, those observed in affected humans (Dutch-Belgian Fragile X Consortium, 1994; D'Hooge et al., 1997; Paradee et al., 1999; Dobkin et al., 2000; van Dam et al., 2000). A study using FVB mice, the strain used in the present study, revealed significant deficits in the Morris water maze in comparison with wildtypes (Dobkin et al., 2000). The morphological abnormalities of synaptic structures in FMRP-deficient humans and mice (namely, increased number of immature dendritic spines and abnormal dendritic morphology), together with the observation that Fmrl mRNA is strongly expressed during brain development and in regions of high synaptic plasticity, an involvement of this protein in synapse maturation and elimination and/or synthesis of proteins related to postsynaptic function was proposed (Comery et al., 1997; Feng et al., 1997; Weiler \& Greenough, 1999; Irwin et al., 2000).

On the neurochemical level, neither human patients nor the mouse mutants displaying the Fragile X syndrome have been analyzed. Therefore, in the study described here, we performed a screening of a wide range of neurotransmitters and neuromodulators, including amino acids and monoamines and their metabolites, for the neurochemical characterization of the Fmrl mouse mutants. We usied high performance liquid chromatography (HPLC) to quantify the basal tissue concentrations of amino acids, i.e. aspartate and glutamate (acting as excitatory neurotransmitters), $\gamma$-aminobutyric acid (GABA) and taurine (acting as inhibitory neurotransmitters/modulators) and glutamine and alanine, as well as monoamines (dopamine, serotonin) and their metabolites in eight distinct brain areas of juvenile (postnatal days 28 to 31 ) and adult (postnatal days 209 to 221) male Fmrl knockout mice and compared with age-matched wildtype animals. 


\section{EXPERIMENTAL}

\section{Animals}

Male wildtype and Fmrl knockout mice with FVB/NJ strain background were genotyped by the polymerase chain reaction (for details see Consortium, 1994) to confirm the normality or mutation of the Fmrl gene in wildtype and knockout mice, respectively. Mice were housed under strictly controlled conditions (light:dark $=12: 12$ hours) with food and water ad libitum. Litters remained with their mother until postnatal day 21 (PND 21), when they were weaned and housed as offspring-groups until used in the experiments. All experimental protocols were approved by the ethical committee of the government of the state of Saxony-Anhalt according to the German guidelines for the care and use of animals in laboratory research $(\S 8$, Abs. 1, 25.05.1998). All experiments were performed in accordance with the European Communities Council Directive of November 1986 (86/609/EEC).

\section{Chemicals}

Dopamine (DA), 3,4-dihydroxyphenylacetic acid (DOPAC), 4-hydroxy-3-methoxyphenylacetic acid (HVA), 3-methoxytyramine (3-MT), serotonin (5-HT), 5-hydroxyindole-3-acetic acid (5-HIAA), ethylenediaminetetraacetic acid, sodium metabisulfite, ortho-phtaldialdehyde, and octanesulfonic acid were purchased from SIGMA (Germany). Perchloric acid, acetonitrile, and methanol were from MERCK (Germany). The compounds aspartate, glutamate, glutamine, taurine, alanine, and GABA were purchased from SERVA (Germany).

\section{Tissue preparation}

Neurochemical measurements were carried out in two groups of age: Juveniles (12 wildtype and 10 Fmrl knockout mice from 8 litters aged PND
28 to 32 ) and adults (8 wildtype and $10 \mathrm{Fmrl}$ knockout mice from 6 litters aged PND 209 to 221).

After decapitation, the brains were quickly removed and placed on an ice-cold dissection plate. Each brain was sectioned into eight different areas: medial prefrontal cortex (mPFC), frontal cortex (includes the orbital, primary motor, and frontal part of the somatosensory cortex), caudal cortex (includes the caudal part of the somatosensory, and the visual cortex), striatum (includes striatum, nucleus accumbes, and ventral pallidum), hippocampus, thalamus (includes thalamic and hypothalamic nuclei, and substantia nigra), cerebellum, and brainstem. The tissue from both hemispheres were pooled and frozen in liquid nitrogen and stored at $-80^{\circ} \mathrm{C}$ until assayed. For the quantification of amino acids and monoamines brain tissue wet weight was determined, and each piece was placed into a vial containing ice-cold homogenization buffer $(0.1 \mathrm{M}$ perchloric acid, 0.1 $\mathrm{mM}$ ethylenediaminetetraacetic acid, $2 \mathrm{mM}$ sodium metabisulfite). After homogenization with an ultrasonic tissue disrupter (Sonoplus HD60, Bandelin, Germany) the samples were centrifuged $(14,000 \mathrm{x}$ $\mathrm{g}$ for $15 \mathrm{~min}$ at $4^{\circ} \mathrm{C}$ ) and the supernatants were filtered through a syringe filter $(0.2$ micron pore size; Whatman, USA) before HPLC analysis.

\section{Reversed-phase HPLC analysis}

For reversed-phase high performance liquid chromatography (HPLC), the supernatants of each sample were divided, using one part for amino acid analysis and one part for measuring monoamines, respectively. Concentrations of the amino acids aspartate, glutamate, glutamine, taurine, alanine, and GABA were determined by automatic precolumn-derivatization using ortho-phtaldialdehyde and fluorescence detection (following a modified version of the method of Lindroth \& Mopper, 1979). Briefly, the HPLC analysis was performed 
on a $\mathrm{C} 18$ reversed-phase column $(125 \times 4 \mathrm{~mm}$, packed with LiChrospher ${ }^{\circledR} 5 \mu \mathrm{m}$, MERCK, Germany), using a non-linear gradient of $5 \%$ to $75 \%$

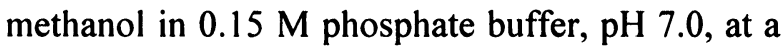
flow rate of $1.5 \mathrm{~mL} / \mathrm{min}$.

Dopamine and its metabolites DOPAC, HVA, and 3-MT, as well as 5-HT and its metabolite 5HIAA, were measured in a single run on an HPLC column $(100 \times 3 \mathrm{~mm}$ packed with YMC ODS$\mathrm{AQ}^{\circledR}, 5 \mu \mathrm{m}, \mathrm{YMC}$, Germany) under isocratic conditions, with electrochemical detection. The mobile phase consisted of a $75 \mathrm{mM}$ phosphate buffer containing $2 \mathrm{mM}$ ethylenediaminetetraacetic acid, $0.1 \mathrm{mM}$ octanesulfonic acid, and $3.5 \%(\mathrm{v} / \mathrm{v})$ acetonitrile ( $\mathrm{pH}$ 4.6). Electrochemical detection was achieved by setting a glassy carbon working electrode at $+780 \mathrm{mV}$ against an $\mathrm{Ag} / \mathrm{AgCl}$ reference electrode of the electrochemical detector (LC4C, BAS, USA).

The final amount in the tissue sample was expressed as micrograms/g wet tissue for amino acids or $\mathrm{ng} / \mathrm{g}$ wet tissue for monoamines, using an external calibration curve.

\section{Statistical analysis}

Values reported are means \pm SEM. Statistical significance for the comparison of genotypes (wildtype vs. Fmrl knockout) was performed by the Mann-Whitney U-test using SigmaStat 2.0 (Jandel, Germany) and considered significant when $p<0.05$.

\section{RESULTS}

For each brain region, we calculated the tissue levels of aspartate, glutamate, glutamine, taurine, alanine, and GABA, as well as the ratio of excitatory and inhibitory amino acids [(aspartate + glutamate)/(taurine $+\mathrm{GABA})]$ for both wildtype and Fmrl knockout mice (see Fig. 1 and Table 1 for juveniles, Fig. 1 and Table 3 for adults), allowing for some assessment of the functional state of the neuronal network. Similarly, the tissue levels of DA, DOPAC, HVA, 3-MT, 5-HT, and 5HIAA, as well as the ratios of DOPAC/DA, HVA/ DA, DOPAC+HVA/DA, and 5-HIAA/5-HT, which reflect changes in monoamine metabolism, were calculated (Table 2 for juveniles and Table 4 for adults). Because the tissue levels of 3-MT were measurable only in the caudal cortex and striatum, and the ratio of 3-MT/DA revealed no significant differences between genotypes, the ratio data are not shown.

In general, knockout of the Fmrl gene was accompanied by age- and region-specific neurochemical alterations. Of all brain areas investigated, the frontal and caudal cortex, striatum, cerebellum, hippocampus, and the brainstem of juvenile mice displayed the most obvious neurochemical differences between wildtype and Fmrl knockout mice. Throughout the analyzed areas in the juvenile brain, the amino acids taurine and aspartate, followed by alanine, glutamine, and GABA, showed the most prominent differences between wildtype and Fmrl knockout mice. Glutamate was unaltered in all regions of both ages which were investigated (Table 1 and Table $3)$. In the caudal cortex, hippocampus, and brainstem of the juvenile Fmrl knockout mice, the balance between excitatory and inhibitory amino acids was shifted toward increased inhibition (Table 1), whereas in adults no difference was found. Differences in the tissue levels and the metabolism of the dopaminergic system were detectable in the frontal cortex, striatum, and cerebellum of juveniles, and in the mPFC and brainstem of adults. The tissue levels and the metabolism of the serotonergic system were affected in the caudal cortex and brainstem of juveniles and in the hippocampus of adults.

In more detail, the following differences between wildtype and Fmrl knockout mice were observed: 

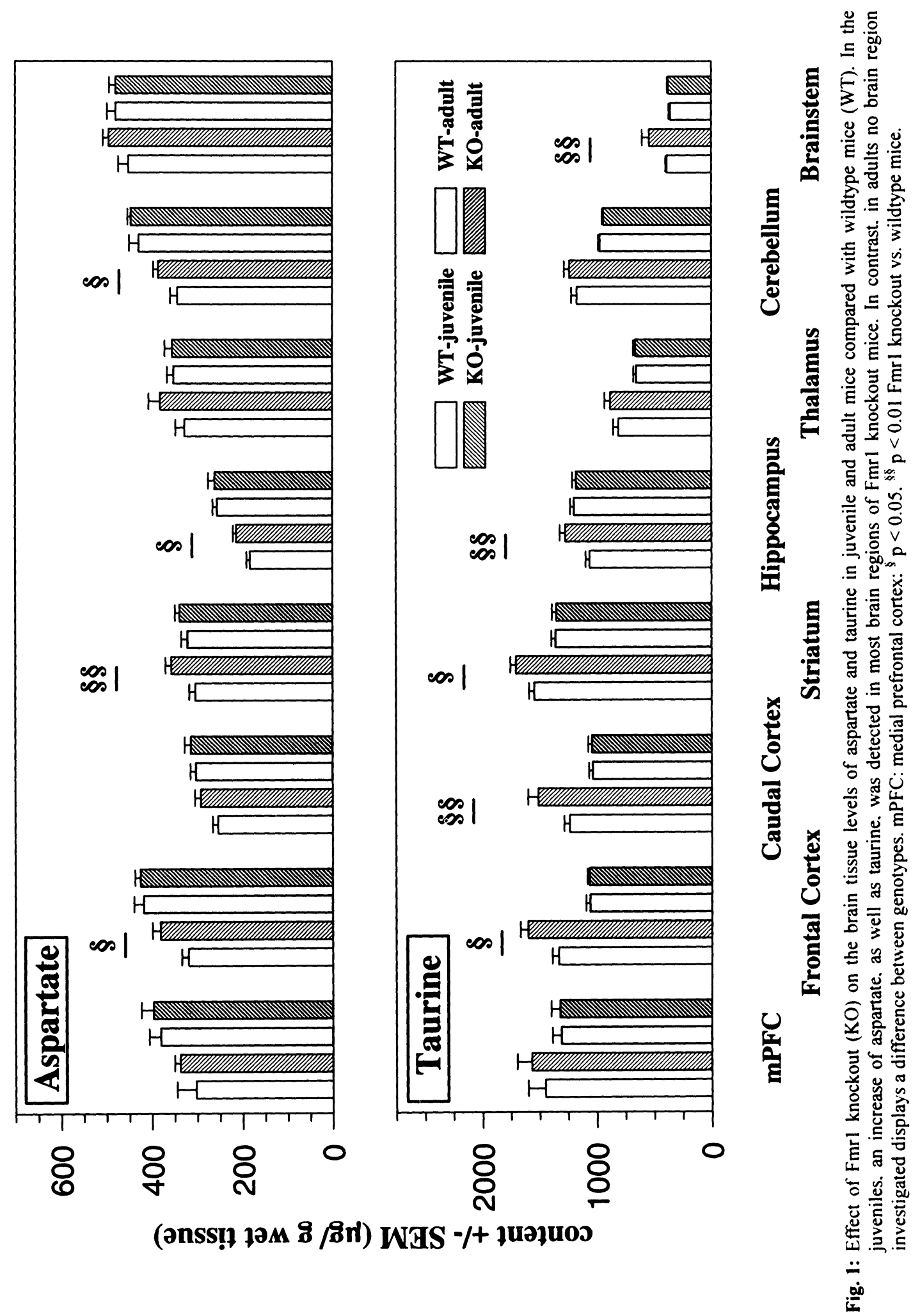


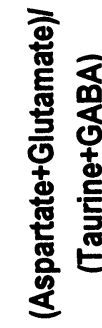

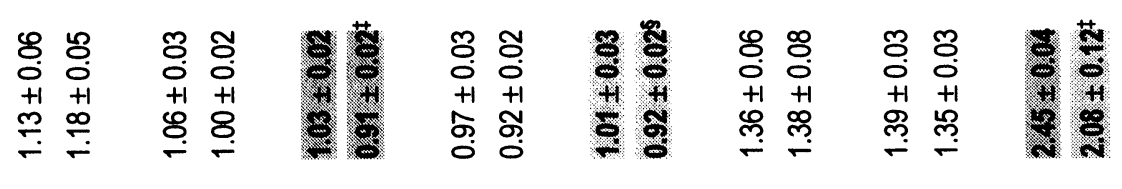

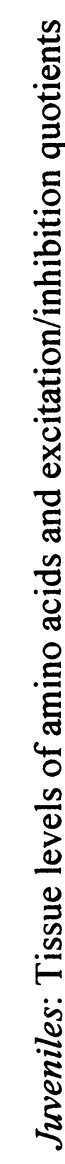

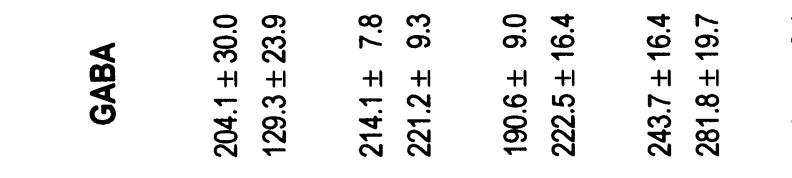

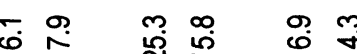

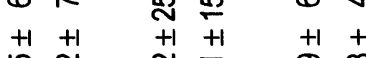

$+1+$ జ

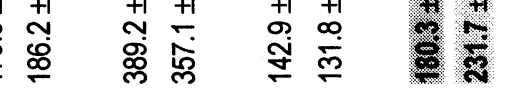

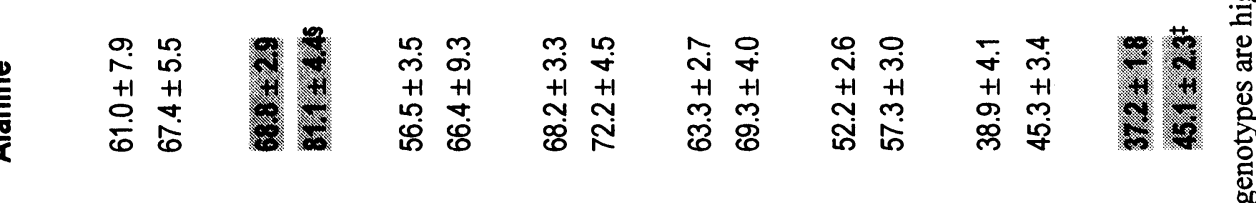

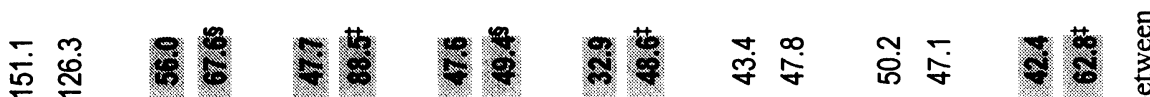

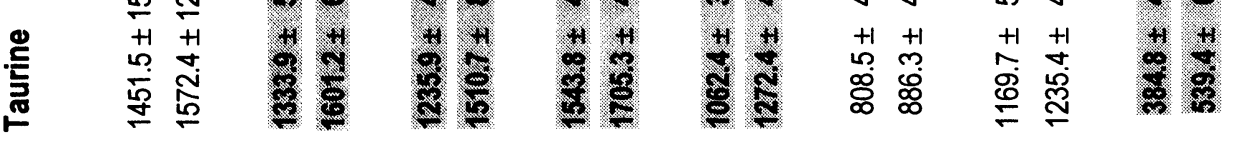

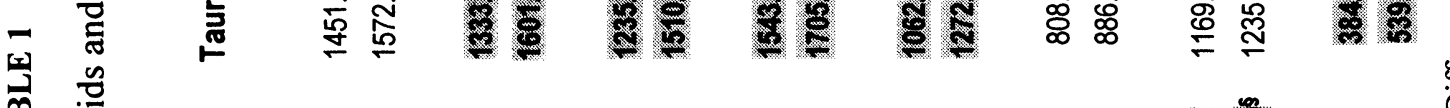

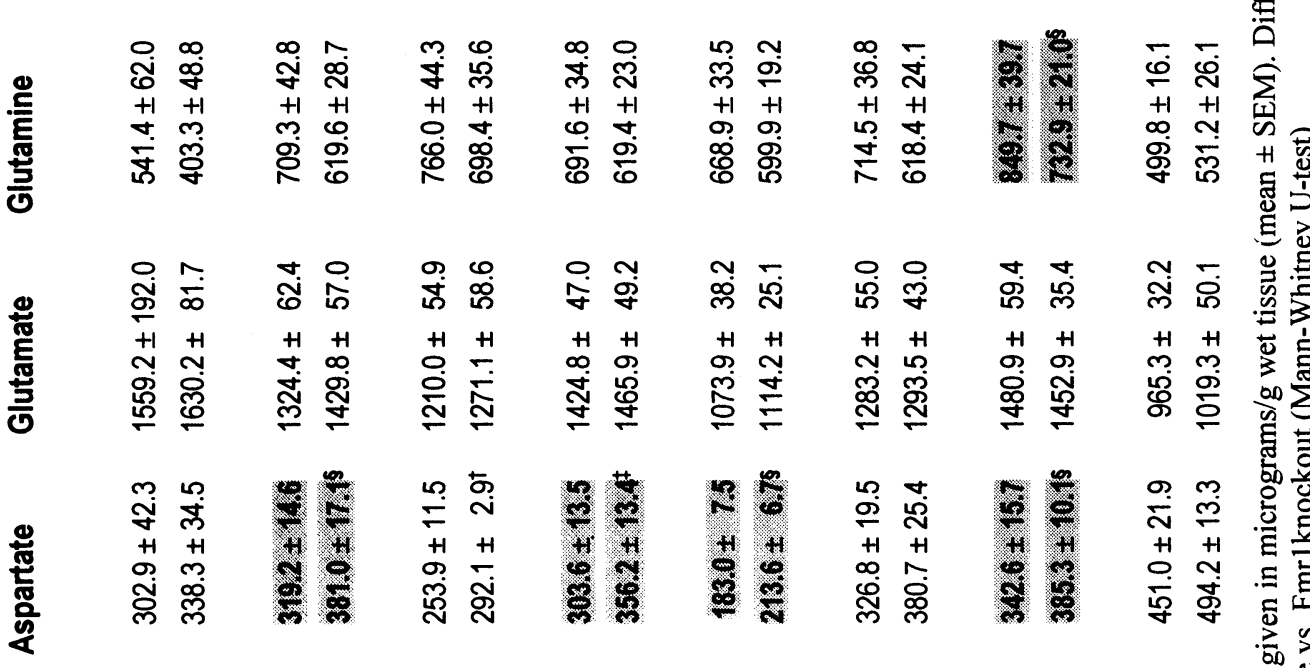

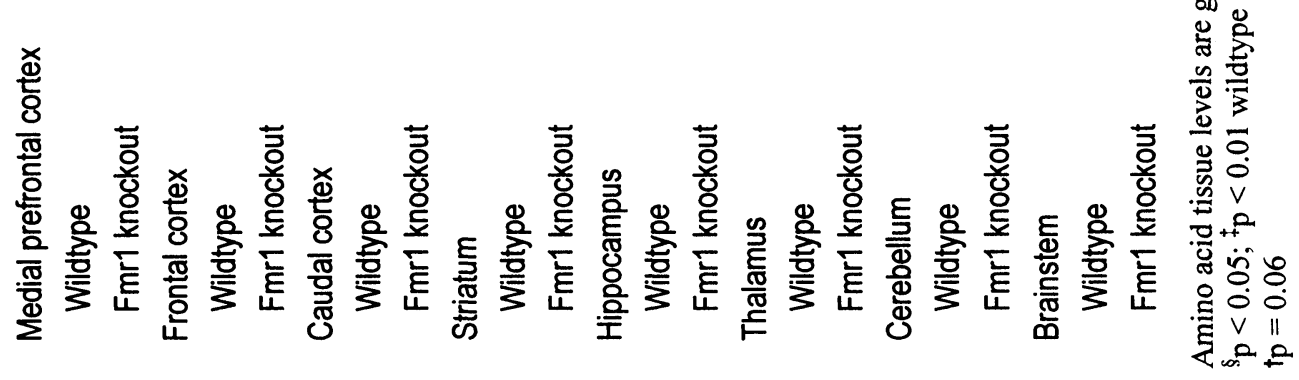




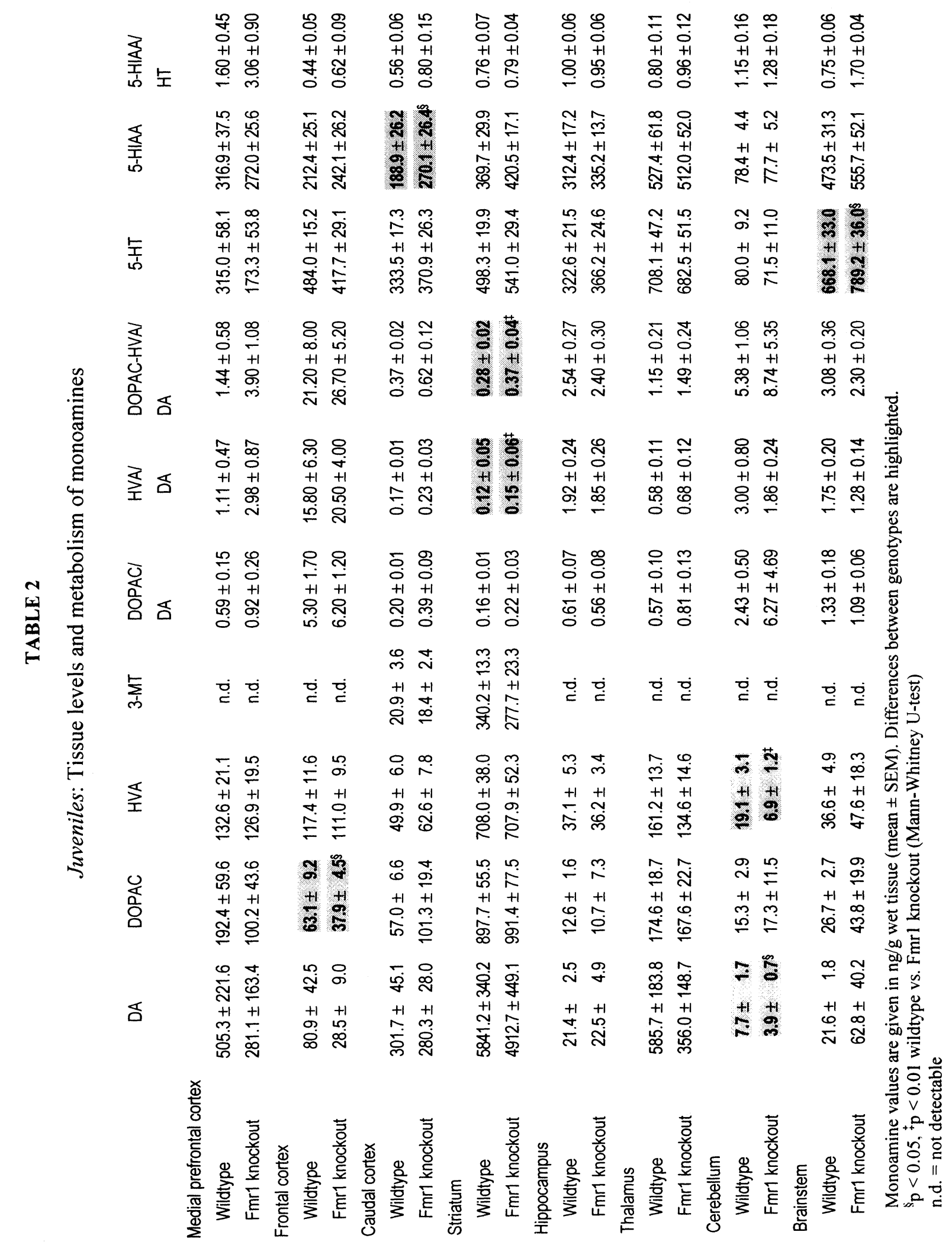




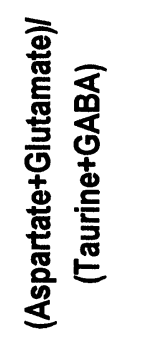

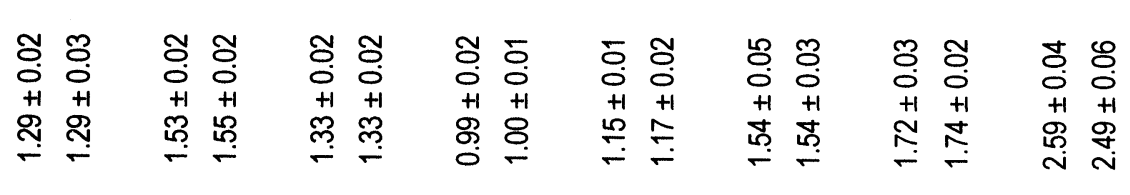

$\frac{\mathscr{0}}{\stackrel{0}{0}}$

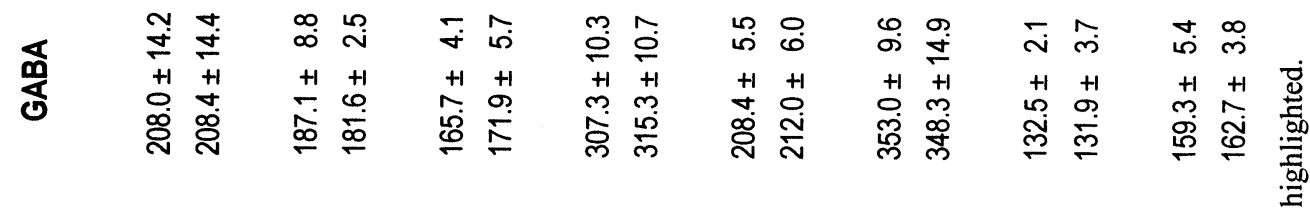

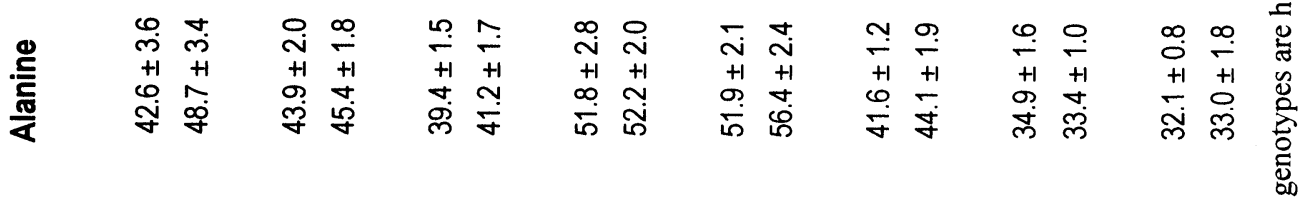

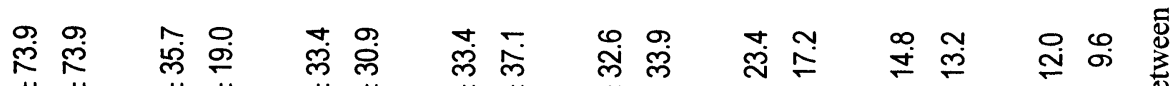

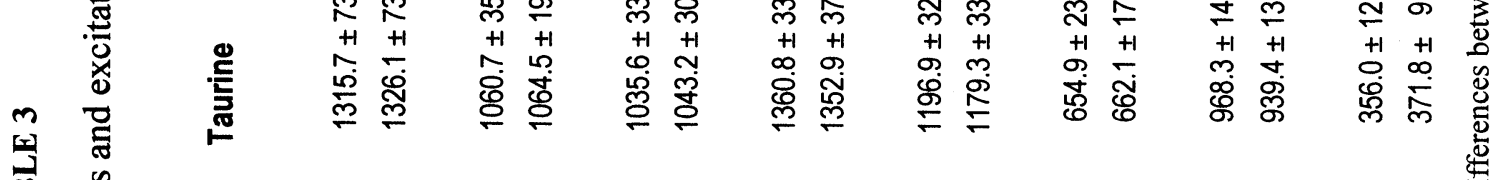

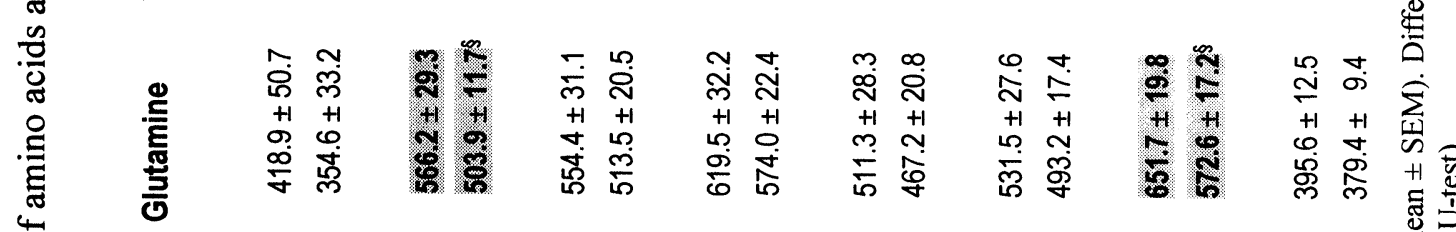

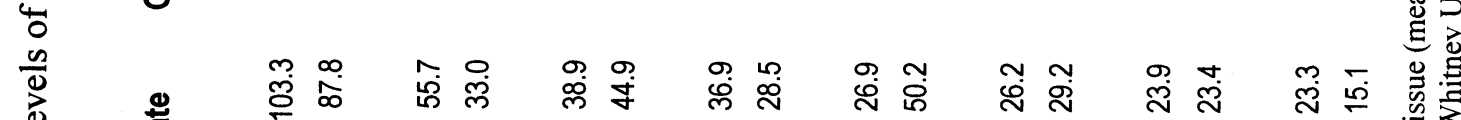

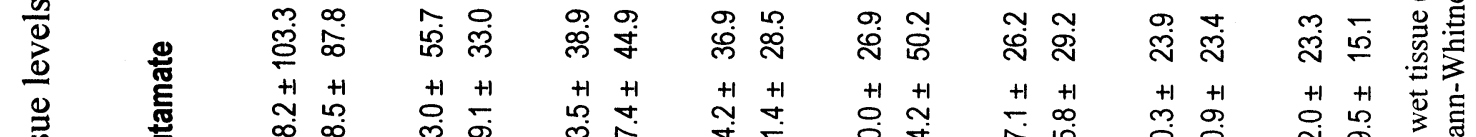

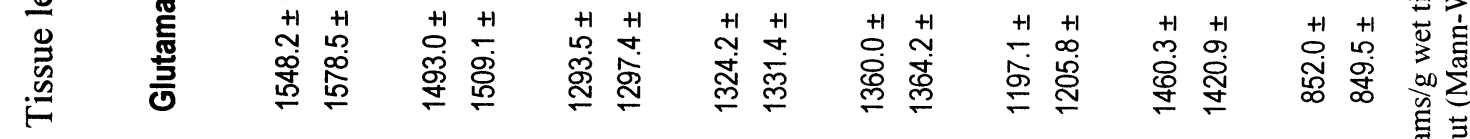

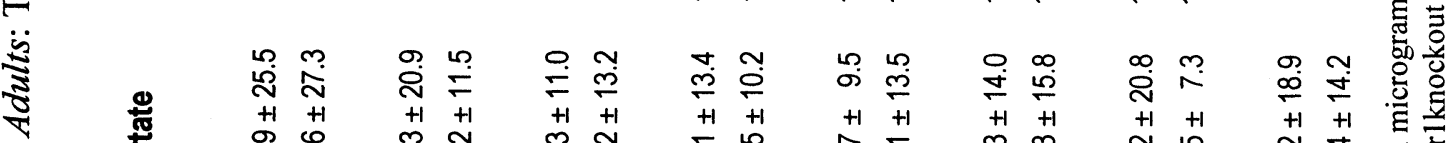

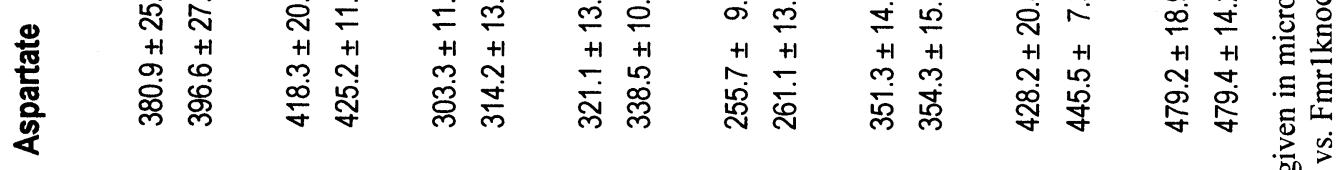

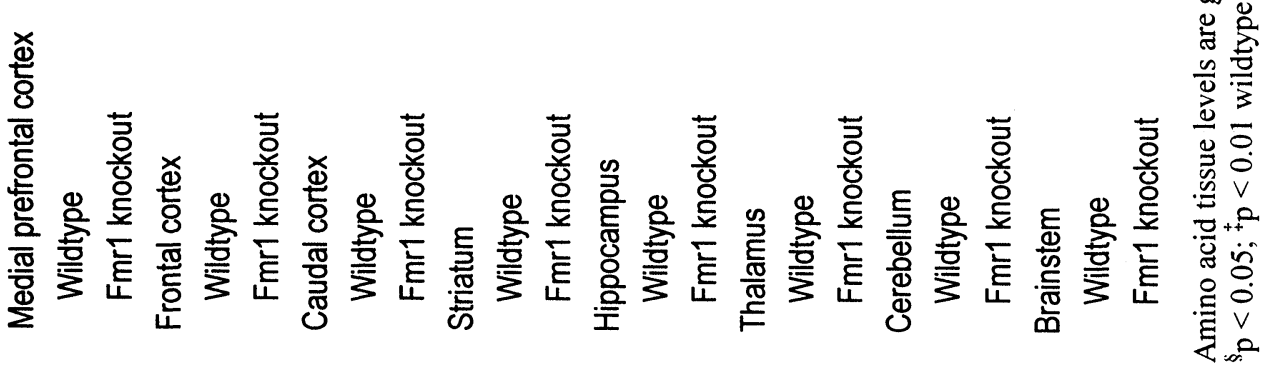




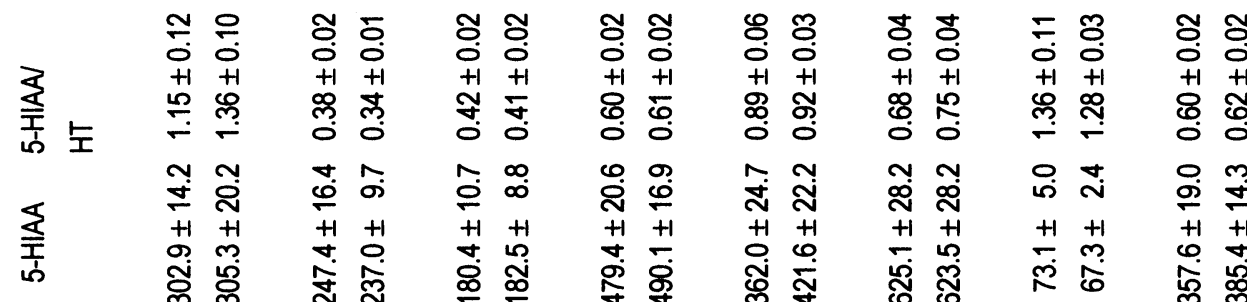

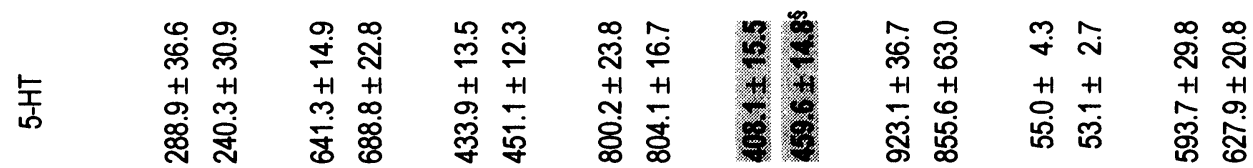

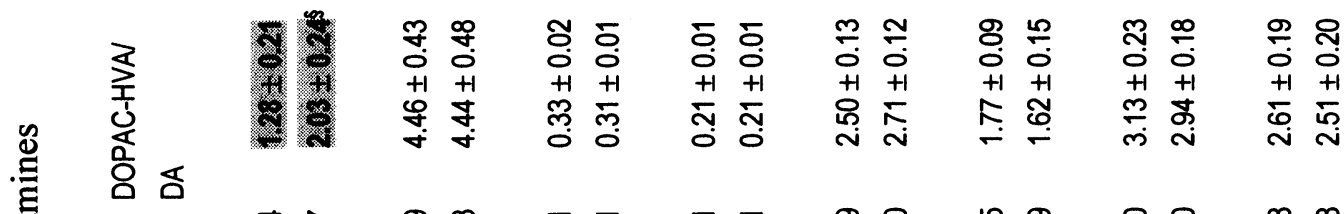

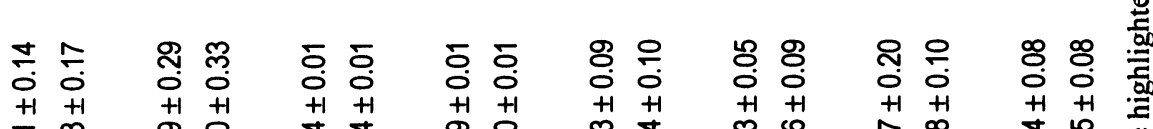

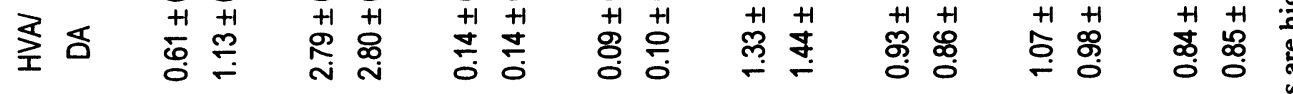

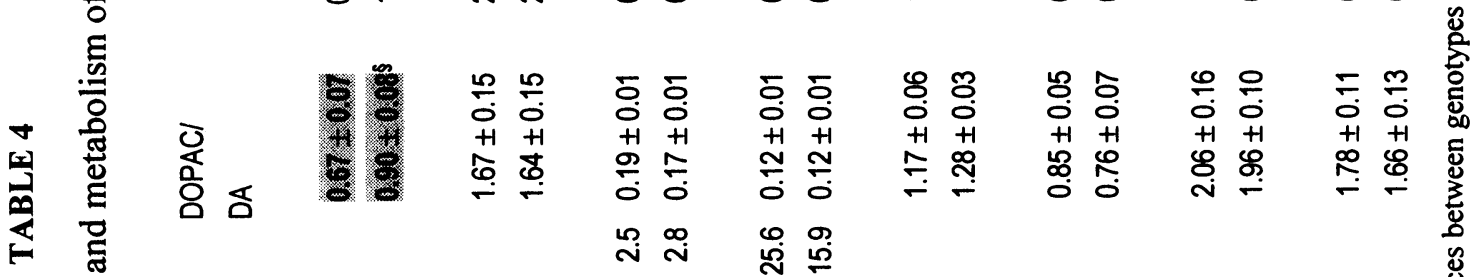

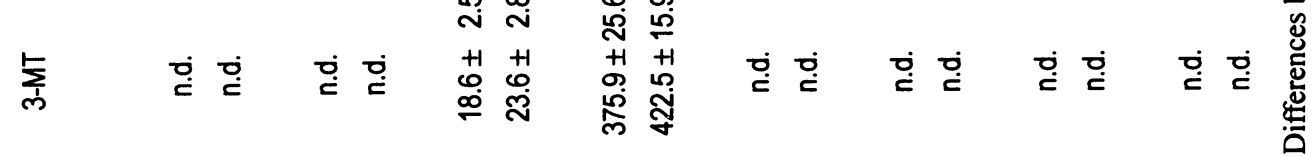

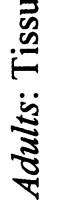

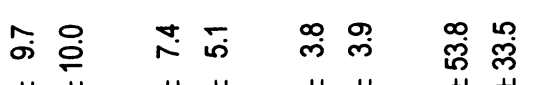

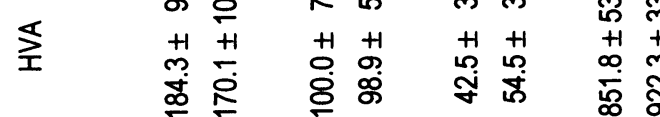

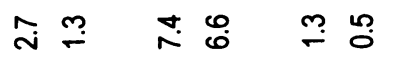

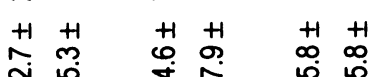

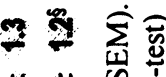
\% $\delta$ \%

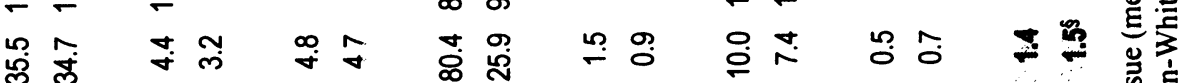

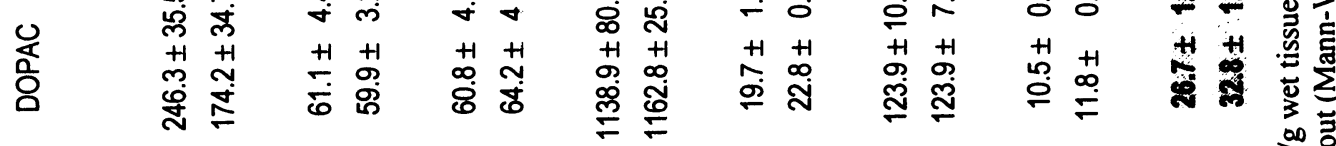

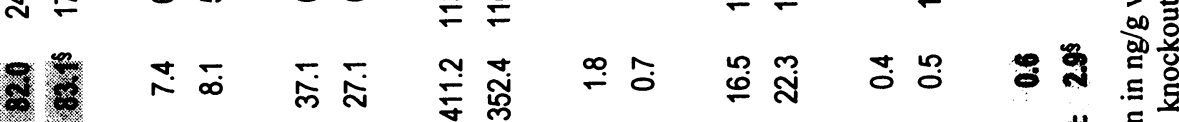

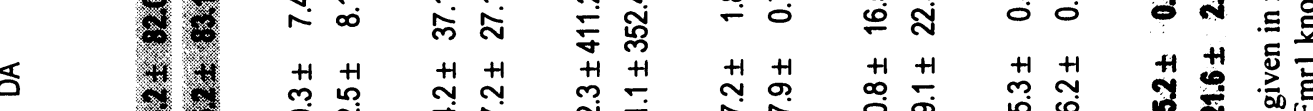

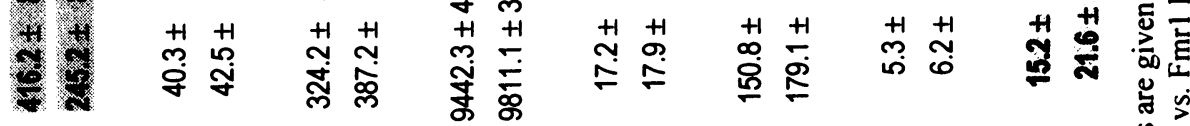

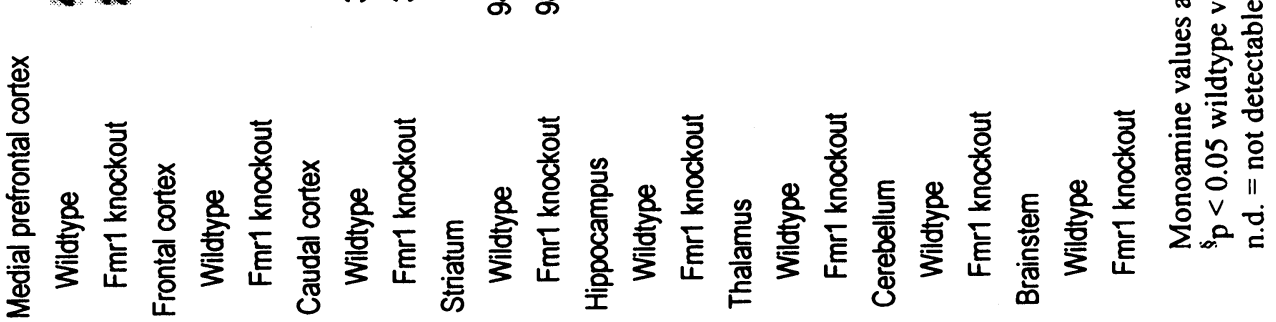


Juveniles: As shown in Fig. 1 and Table 1, when compared with wildtype mice, aspartate was significantly increased in Fmr1 knockout mice in the frontal cortex $(+19 \%)$, striatum $(+17 \%)$, hippocampus $(+17 \%)$, and cerebellum $(+12 \%)$.

Glutamine was significantly decreased in the cerebellum $(-14 \%)$. Taurine was significantly increased in frontal cortex $(+20 \%)$, caudal cortex $(+22 \%)$, striatum $(+10 \%)$, hippocampus $(+20 \%)$, and brainstem $(+40 \%)$. The levels of alanine were increased in the frontal cortex $(+18 \%)$, and brainstem $(+21 \%)$. GABA: an increase in the brainstem $(+29 \%)$ was measured. When compared with wildtype mice, the ratio of (aspartate+ glutamate)/ (taurine+GABA) in Fmrl knockout mice was lower in the caudal cortex $(-12 \%)$, hippo-campus (-9\%), and brainstem $(-15 \%)$.

As indicated in Table 2, tissue levels of DA were decreased in cerebellum $(-49 \%)$, and DOPAC levels were decreased in the frontal cortex $(-40 \%)$. The amounts of HVA were decreased in cerebellum (-64\%). Whereas the ratio of DOPAC/DA was unchanged in all brain regions, the $H V A / D A$ ratio was increased in the striatum $(+25 \%)$. The ratio of $D O P A C+H V A / D A$ showed significant differences between the two genotypes in the striatum $(+32 \%)$. In Fmrl knockout mice, tissue levels of 5-HT were increased in the brainstem exclusively $(+18 \%)$. The levels of 5-HIAA were increased only in the caudal cortex $(+43 \%)$. When characterizing the metabolism of serotonergic neurons, we obtained no significant differences of the 5-HIAA/5-HT ratio.

Adults: In contrast to the juvenile brain, the adult animals displayed only a few significant differences between wildtype and Fmrl knockout mice (Fig. 1, Tables 3 and 4). For amino acids, only glutamine was decreased in the frontal cortex $(-11 \%)$ and cerebellum $(-12 \%)$.

The tissue levels of DA were decreased in the mPFC $(-41 \%)$ and increased in the brainstem $(+42 \%)$ of Fmrl knockout mice compared with wildtype mice. The amounts of DOPAC $(+23 \%)$ and HVA $(+31 \%)$ were increased in the brainstem. The ratio of $D O P A C / D A$ was increased in the mPFC ( $+34 \%)$, but the $H V A / D A$ ratio showed no significant change. The ratio of $D O P A C+H V A / D A$ was increased in the mPFC $(+59 \%)$. Whereas the levels of 5-HT were increased in the hippocampus $(+13 \%)$, the amounts of 5-HIAA showed no significant differences between genotypes throughout the brain areas investigated. Furthermore, no changes of the 5-HIAA/5-HT ratio were observed.

\section{DISCUSSION}

The present data comparing wildtype and Fmrl knockout mice on the neurochemical level provide the first evidence that lack of FMRP expression in male mice is paralleled by age- and region-specific abnormalities in basal tissue levels of amino acids and monoamine metabolism, as well as an altered balance between excitatory and inhibitory amino acid transmitter systems. In summary:

i) those brain regions which are known for high expression of FMRP in normal subjects, namely, cortex, striatum, hippocampus, and cerebellum (Abitbol et al., 1993; Hinds et al., 1993; Hergersberg et al., 1995; Feng et al., 1997), and in addition the brainstem, displayed the most obvious differences between both genotypes;

ii) numbers of neurochemical differences between wildtype and Fmrl knockout mice were higher in juveniles (23 significant differences) than in adults ( 9 significant differences);

iii) in juvenile brains, the most affected substrates were the amino acids, especially taurine and aspartate, which showed elevated basal levels in Fmr1 knockout mice; neither juveniles nor adults showed significant alterations between genotypes in the most abundant excitatory amino acid, glutamate; 
iv) the decreased ratio of excitation/inhibition, namely, (aspartate+glutamate)/(taurine+GABA), in juvenile wildtype mice implies an increased level of neuronal inhibition in caudal cortex, hippocampus, and brainstem of Fmrl knockout mice;

v) very few differences between genotypes were found for monoamine metabolism; in juveniles, increased metabolism of dopamine was found exclusively in the striatum, whereas in adults, increased metabolism was found in the $\mathrm{MPFC}$; differences in serotonin metabolism were measured in neither juveniles nor adults.

It is widely accepted, that the precise local and temporal interplay between excitatory and inhibitory neural activity is of critical importance for the formation of the final arrangement of functional neuronal connections (Singer, 1995; Katz \& Shatz, 1996; Micheva \& Beaulieu, 1997; Yuste \& Sur, 1999). The precise causal relationship between neurochemical and the morphological, as well as behavioral, abnormalities in Fmr1 knockout mice remains to be analyzed by further studies, in particular whether altered amino acids, as well as the mismatch of excitation/inhibition, are the consequence of or the cause for the structural and behavioral abnormalities described for the Fragile $\mathrm{X}$ syndrome.

Taurine, which was elevated in various brain regions of juvenile Fmrl knockout mice, is assumed to play a role as an inhibitory neurotransmitter or neuromodulator (Pasantes-Morales \& Gamboa, 1980; Huxtable, 1989; 1992; Oja \& Kontro, 1990), in addition to its role in osmoregulation, protein phosphorylation, calcium regulation, membrane stabilization, and as a trophic factor during neurodevelopment (Huxtable, 1989; 1992; Lima, 1999; Neuringer et al., 1994; Palackal et al., 1986; Sturman, 1993). Since it has been suggested that in the developing brain, taurine rather than GABA is the major inhibitor of neuronal excitation, especially during phases when GABA may still have excitatory function (van den Pol et al., 1998; Khalilov et al., 1999; Leinekugel et al., 1999), high levels of taurine during early postnatal phases (Agrawal et al., 1968; Miller et al., 2000) might suppress electrical activity at a time when other inhibitory systems (GABA) are not yet fully matured (Huxtable, 1989). The role of aspartate, the second amino acid that showed significant alterations in Fmr1 knockout mice, in synaptic transmission is controversial. A recent study has strengthened the evidence for a transmitter role of aspartate in excitatory fiber systems, for example, in the hippocampus (Gundersen et al., 1998).

Taking together the excitatory (glutamate and aspartate) and inhibitory (taurine and GABA) transmitters, the decreased ratio of (aspartate + glutamate)/(taurine + GABA) in juvenile but not in adult Fmrl knockout mice indicates a shift toward increased neuronal inhibition, especially in the caudal cortex, hippocampus, and brainstem of young mice. Such an altered balance of excitation and inhibition in young, but not in adult Fmrl knockout mice could explain the electrophysiological findings of reduced hippocampal long-term potentiation (LTP) in juvenile Fmrl knockout mice as compared with wildtype mice (Aggoun et al., 1999). In adult mice, no differences in basal electrical activity and induction of LTP could be found (Godfraind et al., 1996; Paradee et al., 1999). The mismatch of excitation/inhibition found in the brainstem could also underlie the enhanced audiogenic seizure susceptibility described for juvenile Fmrl knockout mice as compared with wildtype mice (Musumeci et al., 2000). Why, in the present study, adult animals no longer showed this mismatch, despite the even more pronounced seizure susceptibility in adult Fragile X knockout animals, (Chen et al., 2001; Musumeci et al., 2000) remains an open question.

The neurochemical abnormalities measured in juvenile Fmrl knockout mice appear to be transient because they are no longer found in the 
brain of adult FMRP-deficient mice. This time window is at the end of the phase of neuronal and synaptic development in the normal brain (White et al., 1997) and matches well with a period of great vulnerability of the neuronal network toward the lack of FMRP expression, which was shown in a recent study (Nimchinsky et al., 2001). Perhaps some compensatory mechanisms that start to act in the juvenile brain (where neurochemical differences between genotypes are clear) gradually counterbalance the neurotransmission back to normal levels in adults.

To what extent the spectrum of neurochemical changes, seen in several brain regions particularly in young animals, may underlie the emotional and mental deficits observed in adult mice lacking FMRP expression requires further investigation. Furthermore, it would be interesting to assess if comparable neurochemical changes occur in human fragile $\mathrm{X}$ patients, and if the magnitude of neurochemical changes correlates with the severity of the mental and/or emotional impairment in humans, as well as in the animal model.

\section{ACKNOWLEDGMENT}

The authors wish to thank to Dr. W.T. Greenough for the generous supply of the mice, to Drs. O. Rilke and J. Oehler, Technical University Dresden, and to Dr. D. Montag, Leibniz Institute for Neurobiology Magdeburg, for technical advice. This work was supported by the FRAXA Foundation, U.S.A.

\section{REFERENCES}

Abitbol M, Menini C, Delezoide AL, Rhyner T, Vekemans M, Mallet J. 1993. Nucleus basalis magnocellularis and hippocampus are the major sites of FMR-1 expression in the human fetal brain. Nature Genet 4: 147-153.
Aggoun D, Diabira D, Kemel ML, Ben-Ari Y, Gozlan H. 1999. Synaptic plasticity and synaptic proteins in mice knockout for FMR1 gene during development. Soc Neurosci Abstr 25: 183.12.

Agrawal HC, Davis JM, Himwich WA. 1968. Developmental changes in mouse brain: weight, water content and free amino acids. J Neurochem 15 917-923.

Ashley CT, Sutcliffe JS, Kunst CB, Leiner HA, Eichler EE, Nelson DL, et al. 1993a. Human and murine FMR-1: Alternative splicing and translational initiation downstream of the CGG-repeat. Nature Genet 4: 244-251.

Ashley CT Jr, Wilkinson KD, Reines D, Warren ST. 1993b. FMR1 protein: conserved RNP family domains and selective RNA binding. Science 262: 563-566.

Bachner D, Manca A, Steinbach P, Wohrle D, Just W, Vogel W, et al. 1993. Enhanced expression of the murine FMR 1 gene during germ cell proliferation suggests a special function in both the male and the female gonad. Human Mol Genet 2: 2043 2050.

Bailey DB, Mesibov GB, Hatton DD, Clark RD, Roberts JE, Mayhew L. 1998. Autistic behavior in young boys with fragile $\mathrm{X}$ syndrome. J Autism Dev Disorders 28: 499-508.

Baumgardner TL, Reiss AL, Freund LS, Abrams MT 1995. Specification of the neurobehavioral phenotype in males with fragile $\mathrm{X}$ syndrome. Pediatrics 95: 744-752.

Chen L, Toth M. 2001. Fragile X mice develop sensory hyperreactivity to auditory stimuli. Neuroscience 103: 1043-1050.

Comery TA, Harris JB, Willems PJ, Oostra BA, Irwin SA, Weiler IJ, et al. 1997. Abnormal dendritic spines in fragile $\mathrm{X}$ knockout mice: maturation and pruning deficits. Proc Natl Acad Sci USA 94 5401-5404.

Devys D, Lutz Y, Rouyer N, Bellocq JP, Mandel JL. 1993. The FMR-1 protein is cytoplasmic, most abundant in neurons and appears normal in carriers of a fragile $\mathrm{X}$ premutation. Nature Genet 4: $335-340$.

D’Hooge R, Nagels G, Franck F, Bakker CE, Reyniers E, Storm K, et al. 1997. Mildly impaired water maze performance in male Fmrl knockout mice. Neuroscience 76: 367--376.

Dobkin C, Rabe A, Dumas R, El Idrissi A, Haubenstock H, Brown WT. 2000. Fmrl knockout mouse 
has a distinctive strain-specific learning impairment. Neuroscience 100: 423-429.

Dutch-Belgian Fragile X Consortium. 1994. Fmr1 knockout mice: A model to study fragile X mental retardation. The Cell 78: 23-33.

Feng Y, Gutekunst CA, Eberhart DE, Yi H, Warren ST, Hersch SM. 1997. Fragile X mental retardation protein: Nucleocytoplasmic shuttling and association with somatodendritic ribosomes. J Neurosci 17: 1539-1547.

Freund LS, Reiss AL. 1991. Cognitive profiles associated with the $\mathrm{fra}(\mathrm{X})$ syndrome in males and females. Am J Med Genet 38: 542-547.

Fu YH, Kuhl DP, Pizzuti A, Pieretti M, Sutcliffe JS, Richards S, et al. 1991. Variation of the CGG repeat at the fragile $X$ site results in genetic instability: resolution of the Sherman paradox. Cell 67: 1047-1058.

Godfraind JM, Reyniers E, De Boulle K, D'Hooge R, De Deyn PP, Bakker CE, et al. 1996. Long-term potentiation in the hippocampus of fragile $\mathrm{X}$ knockout mice. Am J Med Genet 64: 246-251.

Gundersen V, Chaudhry FA, Bjaalie JG, Fonnum F, Ottersen OP, Storm-Mathisen J. 1998. Synaptic vesicular localization and exocytosis of L-aspartate in excitatory nerve terminals: A quantitative immunogold analysis in rat hippocampus. J Neurosci 18: 6059-6070.

Hagerman RJ. 1996. Physical and behavioral phenotype. In: Hagerman RJ, Cronister A, eds, Fragile X syndrome: Diagnosis, treatment and research. Baltimore, Maryland, USA: John Hopkins University Press; 3-87.

Hergersberg M, Matsuo K, Gassmann M, Schaffner W, Luscher B, Rulicke T, et al. 1995. Tissuespecific expression of a FMR1/beta-galactosidase fusion gene in transgenic mice. Hum Mol Genet 4: 359-366.

Hinds HL, Ashley CT, Sutcliffe JS, Nelson DL, Warren ST, Housman DE, et al. 1993. Tissue specific expression of FMR-1 provides evidence for a functional role in fragile $\mathrm{X}$ syndrome. Nature Genet 3: 36-43.

Hinton VJ, Brown WT, Wisniewski K, Rudelli RD. 1991. Analysis of neocortex in three males with the fragile $X$ syndrome. Am J Med Genet 41: 289-294.

Huxtable RJ. 1989. Taurine in the central nervous system and the mammalian actions of taurine. Prog Neurobiol 32: 471-533.
Huxtable RJ. 1992. Physiological actions of taurine. Physiol Rev 72: 101-163.

Irwin SA, Galvez R, Greenough WT. 2000. Dendritic spine structural anomalies in fragile- $\mathrm{X}$ mental retardation syndrome. Cereb Cortex 10: 10381044.

Irwin SA, Patel B, Idupulapati M, Harris JB, Crisostomo RA, Larsen BP, et al. 2001. Abnormal dendritic spine characteristics in the temporal and visual cortices of patients with fragile-X syndrome: A quantitative examination. Am J Med Genet 98: 161-167.

Jin P, Warren ST. 2000. Understanding the molecular basis of fragile-X syndrome. Hum Mol Genet 9: 901-908.

Katz LC, Shatz CJ. 1996. Synaptic activity and the construction of cortical circuits. Science 274: 1133-1138.

Khalilov I, Dzhala V, Ben-Ari Y, Khazipov R. 1999. Dual role of GABA in the neonatal rat hippocampus. Dev Neurosci 21: 310-319.

Khandjian EW, Fortin A, Thibodeau A, Tremblay S, Cote F, Devys D, et al. 1995. A heterogeneous set of FMR 1 proteins is widely distributed in mouse tissues and is modulated in cell culture. Hum Mol Genet 4: 783-789.

Leinekugel $\mathrm{X}$, Khalilov I, McLean H, Caillard O, Gaiarsa JL, Ben-Ari Y, et al. 1999. GABA is the principal fast-acting excitatory transmitter in the neonatal brain. Adv Neurol 79: 189-201.

Lima L. 1999. Taurine and its trophic effects in the retina. Neurochem Res 24: 1333-1338.

Lindroth P, Mopper K. 1979. High performance liquid chromatographic determination of sub-picomole amounts of amino acids by precolumn fluorescence derivatization with o-pthaldialdehyde. Anal Chem 51: 1667-1674.

Micheva KD, Beaulieu C. 1997. Development and plasticity of the inhibitory neocortical circuitry with an emphasis on the rodent barrel field cortex: A review. Can J Physiol Pharmacol 75: 470-478.

Miller TJ, Hanson RD, Yancey PH. 2000. Developmental changes in organic osmolytes in prenatal and postnatal rat tissues. Comp Biochem Physiol A Mol Integr Physiol 125: 45-56.

Musumeci SA, Bosco P, Calabrese G, Bakker C, De Sarro GB, Elia M, et al. 2000. Audiogenic seizures susceptibility in transgenic mice with fragile $X$ syndrome. Epilepsia 41: 19-23

Neuringer M, Palackal T, Sturman JA, Imaki H. 1994. 
Effects of postnatal taurine deprivation on visual cortex development in rhesus monkeys through one year of age. Adv Exp Med Biol 359: 385-392.

Nimchinsky EA, Oberlander AM, Svoboda K. 2001. Abnormal development of dendritic spines in FMR1 knockout mice. J Neurosci 21: 5139-5146.

Oberle I, Rousseau F, Heitz D, Kretz C, Devys D, Hanauer A, et al. 1991. Instability of a 550-base pair DNA segment and abnormal methylation in fragile X syndrome. Science 252: 1097-1102.

Oja SS, Kontro P. 1990. Neuromodulatory and trophic actions of taurine. Prog Clin Biol Res 351: 69-76.

Oostra BA. 1996. Fragile X syndrome in humans and mice. Acta Genet Med Gemellol (Roma) 45: 93 108.

Oostra BA, Hoogeveen AT. 1997. Animal model for fragile X syndrome. Ann Med 29: 563-567.

Palackal T, Moretz R, Wisniewski H, Sturman J. 1986. Abnormal visual cortex development in the kitten associated with maternal dietary taurine deprivation. J Neurosci Res 15: 223-239.

Paradee W, Melikian HE, Rasmussen DL, Kenneson A, Conn PJ, Warren ST. 1999. Fragile X mouse: strain effects of knockout phenotype and evidence suggesting deficient amygdala function. Neuroscience 94: 185-192.

Pasantes-Morales H, Gamboa A. 1980. Effect of taurine on ${ }^{45} \mathrm{Ca}^{2+}$ accumulation in rat brain synaptosomes. J Neurochem 34: 244-246.

Pieretti M, Zhang FP, Fu YH, Warren ST, Oostra BA, Caskey CT, et al. 1991. Absence of expression of the FMR-1 gene in fragile $X$ syndrome. Cell 66 : 817-822.

Reiss AL, Abrams MT, Greenlaw R, Freund L, Denckla MB. 1995. Neurodevelopmental effects of the FMR-1 full mutation in humans. Nature Med 1: 159-167.

Reiss AL, Aylward E, Freund LS, Joshi PK, Bryan RN. 1991a. Neuroanatomy of fragile X syndrome: the posterior fossa. Ann Neurol 29: 26-32.

Reiss AL, Freund L, Tseng JE, Joshi PK. 1991 b. Neuroanatomy in fragile $\mathrm{X}$ females: The posterior fossa. Am J Hum Genet 49: 279-288.

Reiss AL, Lee J, Freund L. 1994. Neuroanatomy of fragile $\mathrm{X}$ syndrome: The temporal lobe. Neurology 44: 1317-1324.

Rudelli RD, Brown WT, Wisniewski K, Jenkins EC, Laure-Kaminowska M, Connell F, et al. 1985. Adult fragile $\mathrm{X}$ syndrome. Acta Neuropath (Berlin) 67: 289-295.

Singer W. 1995. Development and plasticity of cortical processing architectures. Science 270: 758-764.

Sturman JA. 1993. Taurine in development. Physiol Rev 73: 119-147.

Turk J, Graham P. 1997. Fragile X syndrome, autism, and autistic features. Autism 1: 175-197.

Van Dam D, D'Hooge R, Hauben E, Reyniers E, Gantois I, Bakker CE, et al. 2000. Spatial learning, contextual fear conditioning and conditioned emotional response in Fmrl knockout mice. Behav Brain Res 117: 127-136.

van den Pol AN, Gao XB, Patrylo PR, Ghosh PK, Obrietan K. 1998. Glutamate inhibits GABA excitatory activity in developing neurons. $J$ Neurosci 18: 10749-10761.

Verkerk A, Pieretti M, Sutcliffe J, Fu YH, Kuhl D, Pizzuti A, et al. 1991. Identification of a gene (FMR-1) containing a CGG repeat coincident with a breakpoint cluster region exhibiting length variation in fragile $\mathrm{X}$ syndrome. Cell 65: 905914.

Weiler IJ, Greenough WT. 1999. Synaptic synthesis of the fragile $\mathrm{X}$ protein: Possible involvement in synapse matuartion and elimination. Am J Med Genet 83: 248-252.

White EL, Weinfeld D, Lev DL. 1997. A survey of morphogenesis during the early postnatal period in PMBSF barrels of mouse Sm1 cortex with emphasis on barrel D4. Somatosens Mot Res 14: 34-55.

Yuste R, Sur M. 1999. Development and plasticity of the cerebral cortex: from molecules to maps. J Neurobiol 41: 1-6. 

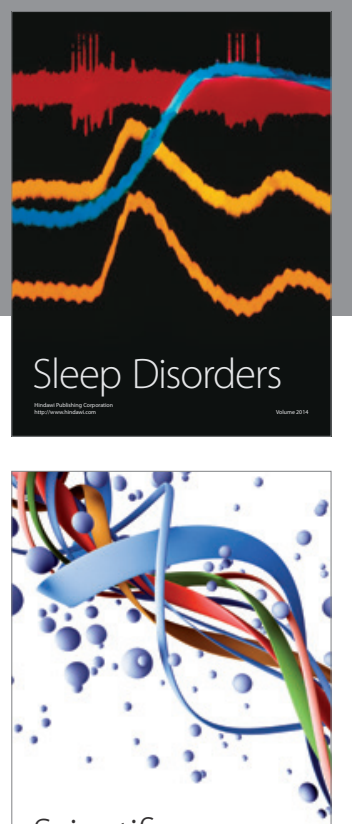

Scientifica
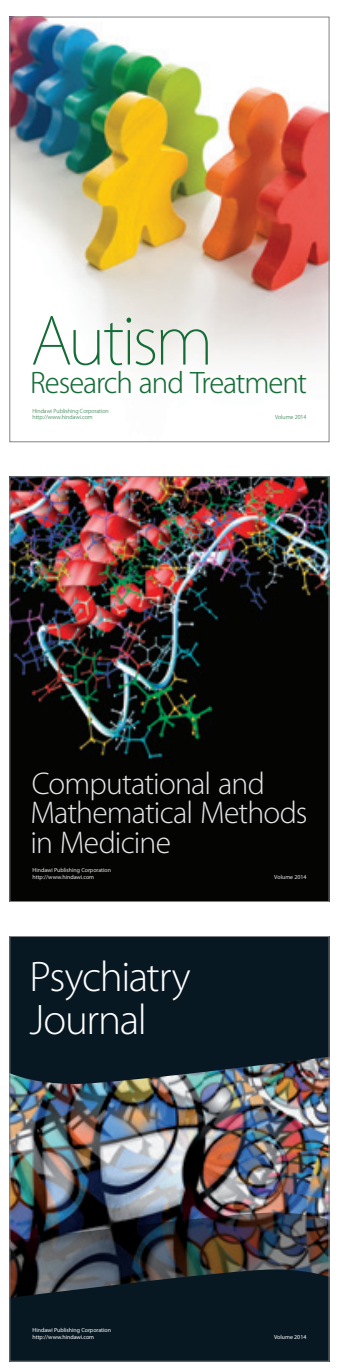
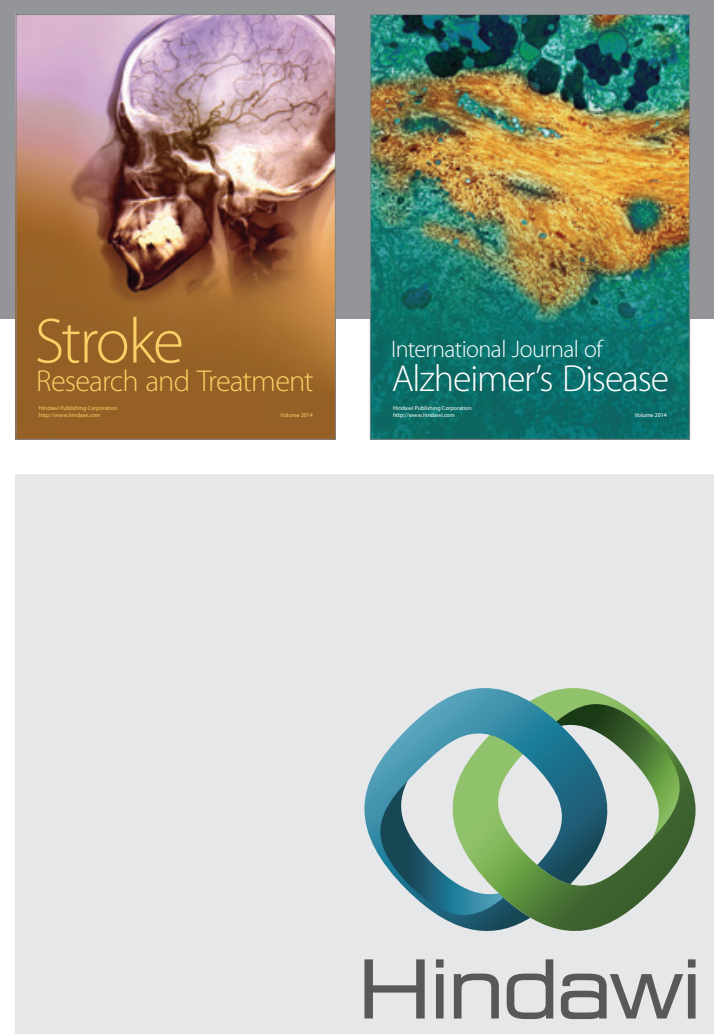

Submit your manuscripts at

http://www.hindawi.com
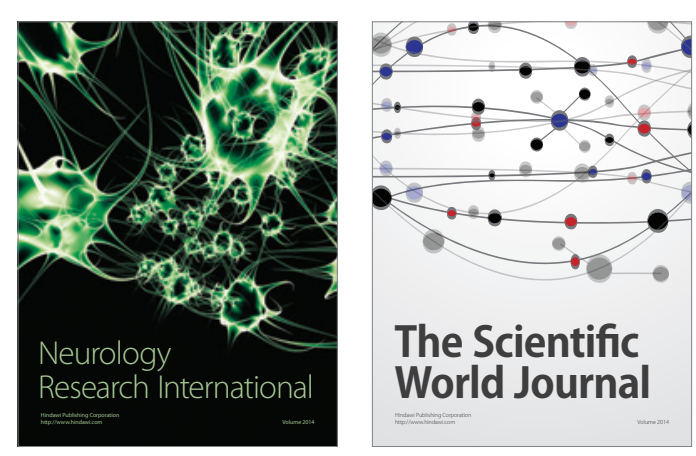

The Scientific World Journal

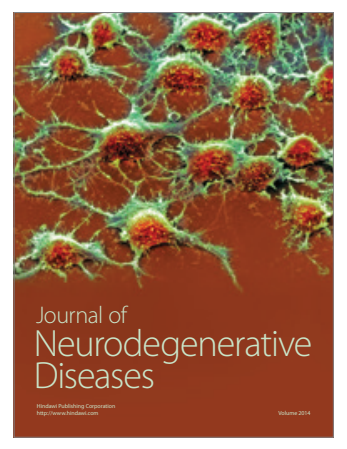

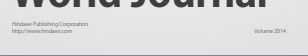

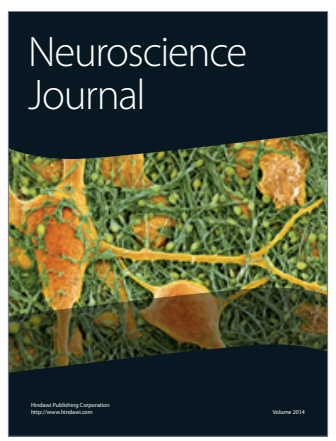

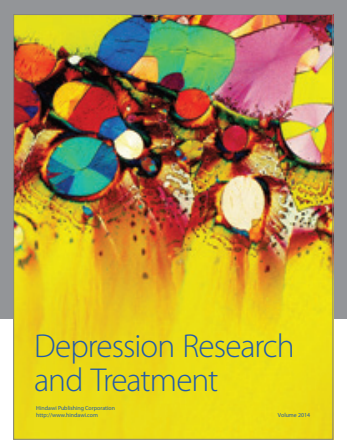
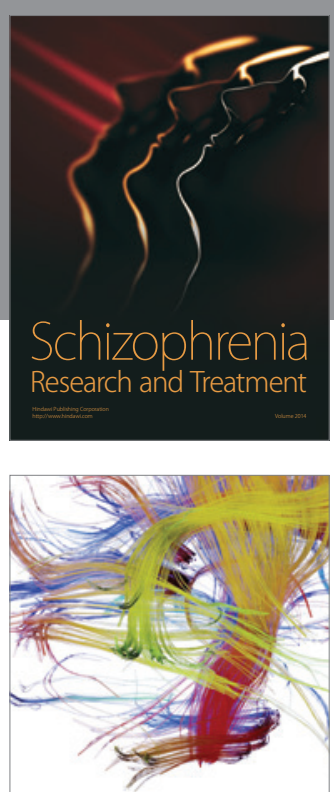

Brain Science

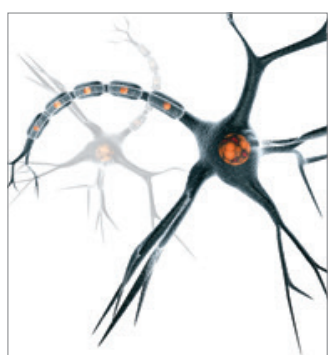

Neural Plasticity
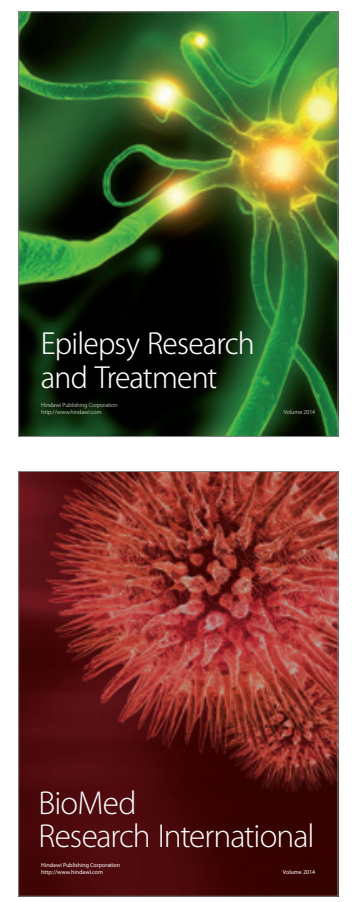

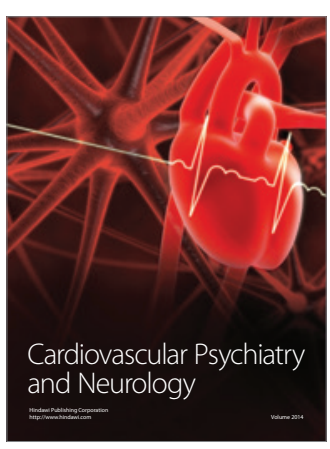

Parkinson's

Disease
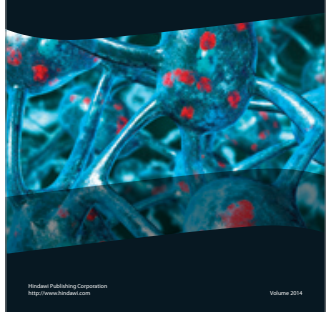